\title{
Environmental change and food security: the special case of small island developing states
}

\author{
Kristen Lowitt $^{1} \cdot$ Arlette Saint Ville $^{1} \cdot$ Patsy Lewis $^{2} \cdot$ Gordon M. Hickey $^{1}$
}

Received: 27 June 2015/Accepted: 22 July 2015/Published online: 7 August 2015

(C) Springer-Verlag Berlin Heidelberg 2015

\begin{abstract}
Small island developing states (SIDS) are recognized as a special case for sustainable development due to the unique set of challenges and vulnerabilities they face. While SIDS are a diverse group of nations, most share characteristics of small size, limited land availability, insularity, susceptibility to natural disasters and deep integration into global markets that make them particularly vulnerable to global environmental and economic change processes. Although there has been considerable research into the impacts of global change processes on small island vulnerability, much less attention has been paid to their resilience, particularly at the intersection of environmental and economic change and the consequences for food security. This paper presents an overview of the socialecological vulnerabilities that drive food and nutrition insecurity in different SIDS contexts and considers how policies and governance arrangements might better support more resilient and sustainable small island food systems drawing from the collection of papers in this Special Issue.
\end{abstract}

Keywords Smallholder farming systems - Complexity · Decentralization - Adaptation - Agricultural innovation systems

\section{Introduction}

It [sugar] was like a heartbeat. 7 o'clock the tractor's going, you hear the women out. It was a culture, and

Kristen Lowitt

kristen.lowitt@mcgill.ca

1 McGill University, Montreal, QC, Canada

2 University of the West Indies, Mona, Jamaica now the culture is gone. Now we're trying to build a new culture around farming - Smallholder farmer, St Kitts

This quote captures the change that has been characteristic of many small islands and their food systems for generations. Despite their small size and insularity, movements of capital, people and fluctuations in natural resources have long shaped these island environments, economies and societies. While many island nations have displayed a remarkable degree of resilience in responding to these changes, their unique social-ecological vulnerabilities are known to be intensifying in a time of increasing globalization and environmental change (McGillivray et al. 2010; Pelling and Uitto 2001; Wong 2011).

Small island developing states (SIDS) were officially recognized as a "special case" for sustainable development by the United Nations (UN) at the Earth Summit in 1992 (Turvey 2007; United Nations 2011). The UN has since classified 52 countries and territories as SIDS, the majority of which are located in the Caribbean and Pacific regions (United Nations 2011). While SIDS are a diverse group, most share the characteristics of small size, limited land availability, insularity, proneness to natural disasters and deep integration into global markets (Pelling and Uitto 2001; Wong 2011).

An area in which the vulnerability of SIDS to global change is increasingly playing out is food security, identified as a priority at the Third International Conference on SIDS convened by the UN in 2014 in Samoa (UNDESA 2014). Environmental change has been recognized as a crucial factor contributing to SIDS-related food insecurity. For example, SIDS are among the most susceptible places to the impacts of climate change (Barnett 2011; Ganpat and Isaac 2014), with more extreme weather events, sea-level 
rise, stressed water resources due to changes in precipitation patterns and acidification of the oceans all posing potentially devastating threats to the agricultural and fisheries resources underlying their local food systems (UNFCC 2007). Interacting with environmental change processes are inequities in global trade, rising food prices, under-developed domestic food systems and limited local food production capacities (Alliance of Small Island States 2012; United Nations 2011). At the household level, food insecurity issues are increasingly presenting themselves in the form of high rates of chronic non-communicable diseases, including diabetes, stroke and hypertension, spurred by more globalized diets and increasing importation of energy-dense foods (Chase et al. 2014; Francis et al. 2010; PAHO2012).

Despite the significance of these issues, existing research and policy responses have been limited and not well integrated. There is subsequently a genuine need to improve our understanding of the different social-ecological contexts affecting food security in SIDS with a view to fostering resilience (Blancard and Hoarau 2013; Campling and Rosalie 2006; Campling 2006; Scheyvens and Momsen 2008).

The collection of papers presented in this Special Issue of Regional Environmental Change seeks to explore and better understand some of the social-ecological factors that drive food and nutrition insecurity in different SIDS contexts and point to ways in which adaptive capacity might be better enhanced through institutions at various scales. In what follows, we present the theoretical background to the papers included in this Special Issue and discuss the implications of their key findings for SIDS food security research and policy agendas.

\section{Theoretical approach}

This Special Issue embraces a social-ecological systems (SES) thinking approach to studying food systems. This approach challenges the view of human and ecological systems as being separate and instead embraces their interdependencies, with human systems a part of, and thus shaping and being shaped by, ecological systems (Berkes and Folke 1998; Berkes et al. 2003). SES thinking has been used to understand a range of natural resource issues in the context of forests and fisheries (e.g., Cilliers et al. 2013; Glaser and Glaeser 2014; Ommer and Neis 2014) and is increasingly being applied to the study of food systems. Ericksen (2008) argued for an SES approach to analyzing the "synergistic effects of the multiple stresses that interact with food systems, sometimes making these systems vulnerable" (p. 14). At the same time, recognizing these interconnections is important to developing more effective and adaptive food security policy (Connolly-Boutin and Smit 2015; Gaire et al. 2014).

A core feature of taking a SES approach to research is the need to focus on issues of vulnerability, adaptive capacity and resilience when analyzing human-ecosystem relations (Cote and Nightingale 2012). Here, resilience can be understood as the capacity of a system "to absorb disturbance and reorganize while undergoing change so as to still retain essentially the same function, structure, identity, and feedbacks" (Walker et al. 2006). Resilience is closely linked to the adaptive capacity of the actors involved, in terms of the potential of the social actors and institutions affecting this system to innovate and respond to change (Eriksen et al. 2009; Olwig 2012). According to Berkes and Ross (2013), adaptive capacity may be viewed as a property of a social-ecological system that can be "activated" through different mechanisms (p. 15). In particular, the ability to innovate ${ }^{1}$ is recognized as a key mechanism for adaptation, often taking place through social networks and learning communities (Berkes and Ross 2013; Amaru and Chhetri 2013).

As individuals and communities develop the capacities to thrive in an environment characterized by change, resilience-building can be enhanced (Berkes and Ross 2013). Taken together, the papers presented in this Special Issue examine the complex and interconnected factors that shape SIDS food systems and consider how their social-ecological resilience can be better supported to facilitate sustainable food security.

\section{Environmental change and food security in SIDS}

The historical social-ecological factors influencing SIDS food systems are well documented in this issue by Connell (2014) and Campbell (2015) in the context of Pacific island food systems and Saint Ville et al.'s (2015) review of agricultural development in the Caribbean. While there are important regional and local differences between SIDS, each of these papers identify a similar pattern of development that has given rise to their food and nutrition security challenges. Key stages in this development included colonization, the establishment of export-oriented production systems and cash economies, a subsequent weakening in systems of food self-provisioning, and most recently a decline, and in some cases complete collapse, of exportoriented agricultural production systems.

Campbell (2015), Connell (2014) and Saint Ville et al. (2015) each provide important insight into the consequences of this history for SIDS food security in the form

\footnotetext{
${ }^{1}$ We understand innovation as an idea, practice or process perceived as novel by a social actor (Rogers 1983).
} 
of under-developed domestic food systems, high reliance on energy-dense food imports and diet-related health problems. Saint Ville et al. (2015) further argue that Caribbean SIDS are struggling to break out of an engrained export-oriented agricultural policy framework which limits their ability to support and develop diverse domestic smallholder farming systems despite the collapse of traditional export commodity markets.

These papers highlight the sensitivity of many SIDS food and agriculture systems to exogenous shocks (Armstrong and Read 2002; Read 2004) which compromises the stability dimension of national food security policy.

Despite the vulnerabilities SIDS face, Allen (2015, this issue) cautions that the narrative of a decline into food insecurity should not be equally applied to all SIDS. Based on case study research conducted in the small Western Pacific Island of Malo, Allen finds considerable evidence of resilience in the island's food system, as communities have forged innovative solutions to food insecurity and sustainability challenges by adapting their traditional practices and institutions to new global realities. Significantly, Allen's work shows us that it is possible for small islands to meaningfully combine export and local production with consumption of local and imported foods to contribute to positive food security outcomes.

Papers by Lowitt et al. (2015a), McConney et al. (2014) and Shah and Dulal (2015) lend further insight into the factors shaping the adaptive capacity of smallholder farmers, small-scale fish harvesters and households, respectively, to respond to food systems' change. Lowitt et al. (2015) examine the factors influencing the innovation potential of smallholder farmers in four Caribbean SIDS. While they identify access to markets, financing and knowledge networks as constraints to innovation, they also find important social interactions missing that are required to create an enabling environment for innovation (Klerkx et al. 2012). Specifically, they observed a pervasive lack of trust among smallholder farmers and other actors in the agricultural system that prevents collective action and coordination on food production-related issues and ultimately erodes their capacity to respond to economic and environmental shocks.

Complementing the agriculture-focused papers in this collection, McConney et al. (2014) present the results of case study research conducted in eight Caribbean fisheries. They identify a lack of participation in management decisions by resource users that contributes to conflict in the industry and weakens its capacity to adapt to sustainability challenges. Paralleling the findings by Lowitt et al. in the smallholder agricultural sector, they also identify a clear lack of trust operating among fish harvesters and between fish harvesters and formal institutions that undermines their capacity to meaningfully communicate and participate in governance processes.

Lastly, Shah and Dulal et al. (2015) examine the factors influencing household vulnerability to food insecurity in the face of extreme weather events in the Caribbean country of Trinidad and Tobago. They find that household socio-demographic characteristics and livelihood strategies are strongly related to food security, but that the level of resilience provided by these factors is significantly reduced in the face of climate variability. Accordingly, they argue that sustainable national food systems must be put in place to help mitigate the impacts of climate change on household food security.

The papers in this collection indicate that SIDS food systems are at a critical juncture. Economic and environmental change is intensifying food security challenges, making learning, adaptation and innovation in institutional structures crucial. Drawing on the various findings presented in this Special Issue, we can identify the general need for more decentralized governance approaches and further context-specific research in SIDS-related food and nutrition security research, policy and practice.

\section{Decentralized governance structures}

In the study of social-ecological systems around the world, a growing literature is attesting to the potential of decentralized governance structures to enhance adaptive capacity to global change (Folke et al. 2005; Lemos and Agrawal 2006). From a social-ecological systems perspective, decentralized governance structures that engage a range of actors and organizations at different scales are capable of fostering the flexibility, diversity and social learning necessary for supporting resilience (Berkes and Ross 2013; Folke et al. 2005; Olsson et al. 2007; Pelling and High 2005). It is important to note that decentralization does not mean that the state has no control or that there is not a need for strong pubic sector institutions (Helling et al. 2015; Lemos and Agrawal 2006). Rather, decentralized governance aims at "finding a balance between decentralized and centralized control" by involving local and higher organizational levels (Folke et al. 2005, p. 449).

In the case of SIDS, the papers presented in this Special Issue generally support the view that experimenting with more decentralized governance approaches to promoting household food security is becoming especially pressing. In many SIDS, hierarchical governance structures developed during earlier colonial periods are becoming increasingly ill-suited to coordinating responses to food insecurity. Papers by Saint Ville et al. (2015) and McConney et al. (2014) argue that the high level of centralized power held by state institutions is constraining the capacity for agricultural system innovation and collective action at local 
levels. This likely contributes to a situation in which communities feel disempowered as they look to the state for leadership, while working connections among citizens and between citizens and institutions remains weak. At the same time, papers by Connell (2014) and Lowitt et al. (2015a) highlight that centralized state institutions have been inadequate on their own in advancing action on resilient food and nutrition security outcomes due to the complexity of the challenge.

Achieving progress on food security in SIDS will ultimately require a departure from more comfortable modes of top-down decision-making to modes that include more decentralized governance mechanisms that foster empowerment, leadership, creativity and accountability in community capacity building mechanisms. More decentralized governance structures may also be able to make better use of local knowledge relevant to natural resource and food production issues, while also bringing decision-makers and researchers closer to those communities most affected by global change processes (Lemos and Agrawal 2006). This may help to build the types of social capital among citizens and institutions crucial for empowering citizens to participate in local development and advancing collective action in support of adaptive capacity (Helling et al. 2015).

The papers in this special issue provide some examples of how such decentralized structures may work to enhance the social-ecological resilience of SIDS food and agriculture systems. For example, McConney et al. (2014) argue for greater participation of fisherfolk, through well-organized social networks in fisheries management to enhance the capacity of these structures to respond to sustainability challenges. Shah and Dulal urge that community planners, policy makers and residents need to work together to develop sustainable national food systems that are less vulnerable to extreme weather events. Lowitt et al. (2015a) suggest that innovation platforms may be useful for bringing together and building trust among actors at different levels of the agricultural innovation system.

These arguments in support of more decentralized governance structures in SIDS align with a growing body of international food security research linking the capacity for collective action to innovation in food systems (Devaux et al. 2009; Kilelu et al. 2013; Markelova et al. 2009). However, we note that in the shift to more decentralized approaches, attention to power and politics is especially important. As Lemos and Agrawal (2006) argued, simply including more social actors does not necessarily make decentralized approaches more democratic. In designing new forms of collaboration, it is crucial to ensure that supportive conditions for meaningful participation by a range of actors, including those historically most marginalized in policy processes, are in place (Lowitt et al. 2015b).

\section{SIDS-specific research needs}

Alongside the need to explore and experiment with more decentralized governance approaches, there remains a need for more context-specific research to support the strategies of individual SIDS to respond to food security challenges. Such research will need to both identify and respond to local priorities and help to inform governance systems (Vogel et al. 2007). Complex systems, including those involving food, are continuously reorganizing and changing, meaning that, "understanding should be continuously updated and adjusted" (Folke et al. 2005, p. 447). This has been a particular challenge in many SIDS, with government ministers from Mauritius and the Seychelles recently speaking out about a lack of appropriate SIDS-specific research support on food and agriculture issues in the face of environmental change (Dobrovolny 2014).

Research can also play an important role in helping build the community strengths and networks that are important to enhancing community adaptive capacity and self-organization (Berkes and Ross 2013). As Berkes and Ross (2013) argued, resilience-building for communities needs to be not only about knowledge and theory but also about practice. Here, research partnerships that engage scientists as well as local practitioners and community members may help contribute to better contextualized and "socially robust" knowledge (Nowotny 2003), while also fostering the community relationships especially important in a SIDS context where relatively low levels of trust and cooperation in agriculture and food systems often exist. Indeed, "genuine and durable partnerships" for promoting sustainable development was the theme of the Third International Conference on SIDS in 2014 (UN 2014). The Samoa Pathway, a series of resolutions adopted at this Conference, affirms international cooperation and multistakeholder partnerships for research and development as a critical component of advancing action on sustainable development, including agricultural research and food security (UN 2014).

\section{Conclusion}

SIDS present a special case for sustainable development and for food security. Global and regional economic and environmental change processes often have disproportionate and inequitable impacts on small island communities due to their limited natural resource bases, small size and deep integration into global economies. This can have very serious implications for household food and nutrition security, potentially affecting the sustainability of fishing and farming systems and the health of the island populations that depend on them for food, nutrition and 
livelihoods. The papers presented in this Special Issue point to a pressing need for food system innovation in different SIDS contexts in order to promote equitable and resilient food and nutrition security. This will likely involve embracing more decentralized governance approaches that are capable of empowering actors, building capacity and developing social capital in support of collective action, coordination and learning. There is, however, an urgent need for more context-specific and participatory research into food and nutrition security issues in different SIDS that better attends to their unique, and often time-sensitive, knowledge needs.

Acknowledgments We would like to thank the anonymous reviewers for their important contribution to the manuscripts presented in this Special Issue. We are also very grateful for the support and assistance provided by the editorial team at Regional Environmental Change.

\section{References}

Allen M (2014) Framing food security in the Pacific Islands: empirical evidence from an island in the Western Pacific. Reg Environ Change. doi:10.1007/s10113-014-0734-5

Alliance of Small Island States (2012) Small islands and food security. Retrieved from http://aosis.org/small-islands-and-foodsecurity/

Amaru S, Chhetri N (2013) Climate adaptation: institutional response to environmental constraints, and the need for increased flexibility, participation, and integration of approaches. Appl Geogr 39:128-139. doi:10.1016/j.apgeog.2012.12.006

Armstrong W, Read RA (2002) The phantom of liberty?: Economic growth and the vulnerability of small states. J Inter Develop 14:435-458. doi:10.1002/jid.886

Barnett J (2011) Dangerous climate change in the Pacific Islands: food production and food security. Reg Environ Change. doi:10. 1007/s10113-010-0160-2

Berkes F, Folke C (eds) (1998) Linking social and ecological systems: management practices and social mechanisms for building resilience. Cambridge University Press, Cambridge

Berkes F, Ross H (2013) Community resilience: towards an integrated approach. Soc Nat Resour 26(1):5-20. doi:10.1080/08941920. 2012.736605

Berkes F, Colding J, Folke C (eds) (2003) Navigating socialecological systems: building resilience for complexity and change. Cambridge University Press, Cambridge

Blancard S, Hoarau J-F (2013) A new sustainable human development indicator for small island developing states: a reappraisal from data envelopment analysis. Econ Model 30(623-635):2012. doi:10.1016/j.econmod.10.016

Campbell J (2014) Development, global change and traditional food security in Pacific Island countries. Reg Environ Change. doi:10. 1007/s10113-014-0697-6

Campling L (2006) A critical political economy of the small island developing states concept: South-south cooperation for island citizens? J Develop Soc 22(3):235-285

Campling L, Rosalie M (2006) Sustaining social development in a small island developing state? The case of Seychelles. Sust Dev 14:115-125. doi:10.1002/sd.298

Chase V, Cherry-Fevrier N, Moore W, Louisy L, Harris M, Stuart S, Gomez C, Gonzales C, Thompson E (2014) Caribbean forum: shaping a sustainable development agenda to address the Caribbean reality in the twenty-first century. Studies and Perspectives Series-the Caribbean-\#26. Retrieved online http:// www.regionalcommissions.org/eclacforum2015.pdf

Cilliers P, Biggs HC, Blignaut S, Choles AG, Hofmeyr JS, Jewitt GPW, Roux DJ (2013) Complexity, modeling, and natural resource management. Ecol Soc 18(3):1. doi:10.5751/ES-05382180301

Connell J (2014) Food security in the island Pacific: Is Micronesia as far away as ever? Reg Environ Change. doi:10.1007/s10113014-0696-7

Connolly-Boutin L, Smit B (2015) Climate change, food security, and livelihoods in sub-Saharan Africa. Reg Environ Change. doi:10. 1007/s10113-015-0761-x

Cote M, Nightingale A (2012) Resilience thinking meets social theory Situating social change in socio-ecological systems (SES) research. Prog Hum Geogr 36(4):475-489. doi:10.1177/ 0309132511425708

Devaux A et al (2009) Collective action for market chain innovation in Andes. Food Policy 34:31-38. doi:10.1016/j.foodpol.2008.10.007

Dobrovolny M (2014, June 23) Small island developing states lack research support. SciDev.Net. Retrieved from http://www. scidev.net/global/r-d/news/small-island-developing-states-lackresearch.html

Ericksen P (2008) Conceptualizing food systems for global environmental change research. Glob Environ Change 18:234-245. doi:10.1016/j.gloenvcha.2007.09.002

Eriksen P, Ingram J, Liverman D (2009) Food security and global environmental change: emerging challenges. Environ Sci Policy 12:373-377. doi:10.1016/j.envsci.2009.04.007

Folke C, Hahn T, Olsson P, Norberg J (2005) Adaptive governance of social-ecological systems. Annu Rev Environ Resour 30:441-473. doi:10.1146/annurev.energy.30.050504.144511

Francis M, Nichols D, Dalrymple N (2010) The effects of a schoolbased intervention programme on dietary intakes and physical activity among primary-school children in Trinidad and Tobago. Public Health Nutrition 13(5):738-747. doi:10.1017/ S1368980010000182

Gaire K, Beilin R, Miller F (2014) Withdrawing, resisting, maintaining and adapting: food security and vulnerability in Nepal. Reg Environ Change. doi:10.1007/s10113-014-0724-7

Ganpat W, Isaac W (eds) (2014) Impacts of climate change on food security in small island developing states. IGI Global, Hershey

Glaser M, Glaeser B (2014) Towards a framework for cross-scale and multi-level analysis of coastal and marine social-ecological systems dynamics. Reg Environ Change. doi:10.1007/s10113014-0637-5

Helling L, Serrano R, Warren D (2015) Linking community empowerment, decentralized governance, and public service provision through a local development framework. SP discussion paper no. 535. World Bank, Washington, DC. Retrieved online http://documents.worldbank.org/curated/en/2005/09/6593614/ linking-community-empowerment-decentralized-governancepublic-service-provision-through-local-development-framework

Kilelu C, Klerkx L, Leeuwis C (2013) Unravelling the role of innovation platforms in supporting co-evolution of innovation: contributions and tensions in a smallholder dairy development programme. Agric Syst 118:65-77. doi:10.1016/j.agsy.2013.03.003

Klerkx L, van Mierlo B, Leeuwis C (2012) Evolution of systems approaches to agricultural innovation: concepts, analysis and interventions. In: Darnhofer I, Gibbon D, Dedieu B (eds) Farming systems research into the 21 st century: the new dynamic, pp 457-483

Lemos M, Agrawal A (2006) Environmental governance. Annu Rev Environ Resour 31:297-325. doi:10.1146/annurev.energy.31. 042605.135621 
Lowitt K (2014) A coastal foodscape: examining the relationship between changing fisheries and community food security on the west coast of newfoundland. Ecology and Society 19(3):48. doi:10.5751/ES-06498-190348

Lowitt K, Hickey G, Saint Ville A, Raeburn K, Thompson-Colón T, Laszlo S, Phillip L (2015a) Factors affecting the innovation potential of smallholder farmers in the Caribbean Community. Reg Environ Change. doi:10.1007/s10113-015-0805-2

Lowitt K, Hickey G, Ganpat W, Phillip L (2015b) Linking communities of practice with value chain development in smallholder farming systems. World Dev 74:363-373

Markelova H, Meinzen-Dick R, Hellin J, Dohrn S (2009) Collective action for smallholder market access. Food Policy 34(1):1-7. doi:10.1016/j.foodpol.2008.10.001

McConney P, Cox S, Parsram K (2014) Building food security and resilience into fisheries governance in the Eastern Caribbean. Reg Environ Change. doi:10.1007/s10113-014-0703-z

McGillivray M, Naude W, Santos-Paulino A (2010) Vulnerability, trade, financial flows and state failure in small island developing states. J Dev Stud 46(5):815-827. doi:10.1080/ 00220381003623822

Nowotny H (2003) Democratising expertise and socially robust knowledge. Sci Public Policy 30(3):151-156. doi:10.3152/ 147154303781780461

Olsson P, Folke C, Galaz V, Hahn T, Schultz L (2007) Enhancing the fit through adaptive co-management: creating and maintaining bridging functions for matching scales in the Kristianstads Vattenrike Biosphere Reserve Sweden. Ecol Soc 12(1):28. http:// www.ecologyandsociety.org/vol12/iss1/art28/

Olwig M (2012) Multi-sited resilience: the mutual construction of "local" and "global" understandings and practices of adaptation and innovation. Appl Geogr 33:112-118. doi:10.1016/j.apgeog. 2011.10.007

Ommer RE, Neis B (2014) Introduction to the special feature on rebuilding fisheries and threatened communities. Ecol Society 19(3):49. doi:10.5751/ES-06960-190349

PAHO/WHO (2012) Provisional agenda item 4.4. CSP 28/9. strategy for the prevention and control of non-communicable diseases. 28th Pan American Sanitary Conference 64th Session of the Regional Committee. Washington, D.C. Retrieved from http:// www.paho.org/hq/index.php?option=com_docman\&task=doc_ view\&gid $=21345 \&$ Itemid

Pelling M, Uitto J (2001) Small island developing states: natural disaster vulnerability and global change. Environ Hazards 3:49-62. doi:10.3763/ehaz.2001.0306

Pelling M, High C (2005) Understanding adaptation: What can social capital offer assessments of adaptive capacity? Glob Environ Change 15:308-319. doi:10.1016/j.gloenvcha.2005.02.001
Read RA (2004) The implications of increasing globalisation and regionalism for the economic growth of small island states. World Develop 32(2):365-378. doi:10.1016/j.worlddev.2003.08. 007

Rogers EM (1983) Diffusion of innovations, 3rd edn. The Free Press of Glencoe, New York

Saint Ville A, Hickey G, Phillip L (2015) Addressing food and nutrition insecurity in the Caribbean through domestic smallholder farming system innovation. Reg Environ Change. doi:10. 1007/s10113-015-0770-9

Scheyvens R, Momsen J (2008) Tourism and poverty reduction: issues for small island states. Tourism Geogr 10(1):22-41. doi:10.1080/14616680701825115

Shah K, Dulal H (2015) Household capacity to adapt to climate change and implications for food security in Trinidad and Tobago. Reg Environ Change. doi:10.1007/s10113-015-0830-1

Turvey R (2007) Vulnerability assessment of developing countries: the case of small-island developing states. Development Policy Review 25(2):243-264. doi:10.1111/j.1467-7679.2007.00368.x

UNDESA (2014) Partnership briefs for small island developing states: water and sanitation, food security and waste management. UN Conference on Small Island Developing States. Retrieved from http://www.sids2014.org/index.php?menu=1549

UNFCC (2007) Vulnerability and adaptation to climate change in small island developing states. Retrieved from http://unfccc.int/ files/adaptation/adverse_effects_and_response_measures_art_ 48/application/pdf/200702_sids_adaptation_bg.pdf

United Nations (2011) Small island developing states: small islands big(ger) stakes. Office of the High Representative for the Least Developed Countries, Landlocked Developing Countries and Small Island Developing States, New York, NY

United Nations (2014) Report of the third international conference on small island developing states. Retrieved from http://www.un. org/ga/search/view_doc.asp?symbol=A/CONF.223/10\&Lang=E

Vogel C, Moser S, Kasperson R, Dabelko G (2007) Linking vulnerability, adaptation, and resilience science to practice: pathways, players, and partnerships. Glob Environ Change 17:349-364

Walker B, Gunderson L, Kinzig A, Folke C, Carpenter S, Schultz L (2006) A handful of heuristics and some propositions for understanding resilience in social-ecological systems. Ecol Soc 11(1):13. http://www.ecologyandsociety.org/vol11/iss1/art13/

Wong PP (2011) Small island developing states. Wiley Interdiscip Rev 2(1):1-6. doi:10.1002/wcc.84 